\title{
Die groot avontuur - wondere van lewe op aarde
}

\author{
OUTEUR: LEON ROUSSEAU
}

HUMAN \& ROUSSEAU

ISBN: 0-7981-4650-8

PRYSR175

Leon Rousseau se Die groot avontuur is 'n populêre wetenskap oor die geskiedenis van lewe op aarde. Populêr-wetenskaplike tekste stel hoë eise aan die skrywer: aktualiteit, toeganklikheid van aanbieding, 'n getroue weergawe van persone en standpunte, duidelike onderskeid tussen feite, teorie en mening en bronne om al drie op te volg. So 'n teks kan ook van twee kante benader word. Die spesialis-wetenskaplike gee 'n blik van binne. Hy ken die parameters, die strydvrae, die persoonlikhede en die interne politiek. Sy probleem is vlak van aanbieding: sit hy te hoog in, verloor hy lesers; stel hy dit te laag, verveel hy sy portuur. Daarteenoor kyk die ingeligte lekeskrywer van buite. Kontroversies en persoonlikhede sien hy gewoonlik in 'n wyer konteks, hy het 'n aanvoeling vir waarvan sy lesers sal hou en kan sy verhaal boeiend vertel. Vir vertolking, feite en teorie bly hy egter van die spesialis afhanklik.

Rousseau val in die tweede kategorie. Hy het geen pretensie om 'n wetenskaplike te wees nie maar sy belangstelling in die natuurwêreld het 'n lang aanloop: joernalis, uitgewer, skrywer van wetenskapsfiksie en die biograaf van Eugene Marais, Suid-Afrika se mees oorspronklike amateurekoloog. Soos Marais verken Rousseau die natuuromgewing met geesdrif, hy beskik oor 'n ruim inligtingsnetwerk en sy soektog word vir hom 'n ontdekking van plekke, persone en idees.

Die teks vleg drie temas saam. Die hooftema is die evolusie van lewe soos geoloë en paleontoloë dit rekonstrueer. Die verhaal begin by die eensellige prokariote 3800 miljoen jaar gelede (mjg) en die daaropvolgende bakens word een vir een afgemerk: eukariote in die Proterosoïkum (2 $000 \mathrm{mjg}$ ), skulpdiere in die Kambrium ( $545 \mathrm{mjg}$ ), dinosourusse in die Jura- en Krytperiodes (tot $65 \mathrm{mjg}$ ) en in detail die ontstaan van mensape en voormense wat 200000 jaar gelede op Homo sapiens uitgeloop het. Tussendeur sny 'n tweede tema, dié van katastrofes: asteroïed-impakte van aardwye omvang, komete en meteoriete wat kontinente verswelg, die groei en krimp van Pleistoseen-ysdekke en vulkaniese uitbarstings soos dié by Yellowstone (2 mjg), Toba (71 000 jg) en Krakatoa (1 883 AD). Die derde tema is meer persoonlik: Rousseau wil die mens se totale geskiedenis nie net wetenskaplik verklaar nie maar in Wilhelm Dilthey se sin van die woord ook verstaan.

Ons keer nou na die norme vir 'n populêre wetenskap terug. Die groot avontuur is in die eerste plek aktueel. Evolusie en veral paleo-antropologie staan vandag in die brandpunt van navorsing, nuwe materiaal kom gedurig tevoorskyn, bondelaars en klowers vat mekaar aan en konsensus neem soms onverwagte wendings. Rousseau stel sy lesers aan hierdie debatte, groot en klein, bekend. Wat lê agter die Perm-uitwissing $251 \mathrm{mjg}$ toe $90 \%$ van alle spesies van die aardbodem verdwyn het? Is die pas-ontdekte "hobbits" van die Indonesiese eiland Flores werklik 'n eie mensspesie, Homo floresiensis, of is hulle bloot pigmieë wat verdere verdwerging ondergaan het? Suid-Afrika se rol word ook prominent in die verhaal ingewerk: Alex du Toit se drywende kontinente wat plaattektoniek geword het, Raymond Dart en die Taungskedel, Hilary Deacon en Sarah Wurz se opgrawings by Klasiesrivier, Uwe Reimold en meteorietimpakte, Hannes Theron en die konodontfossiele van die Sederberg.

Rousseau se taalgebruik, in die tweede plek, is toeganklik en sy passie vir bondige Afrikaans kom in sowel organisasie as styl tot uiting. Die teks van 323 bladsye is in 70 kort hoofstukke 
verdeel, elkeen om 'n enkele episode, konsep of persoon geweef en onder 'n glashelder opskrif saamgevat. Rousseau se vertellings is pakkend, hy skryf dikwels in die eerste persoon, stel sy informante direk aan die woord en verstaan die kuns van transponering. Die Vredefort-asteroïedimpak van $2023 \mathrm{mjg}$ word byvoorbeeld na die verstedelikte Hoëveld van die 21ste eeu oorgedra en Rousseau se bootvasmeerplek in Zeekoeivlei word die toneel van die Saldanha-mens se jag van 600000 jaar gelede. Vakterme word ongemerk in die teks verduidelik, hul herkoms opgevolg en waar nodig met 'n eie woordeskat aangevul.

Ongelukkig dek Die groot avontuur so 'n wye veld dat nuanses oor standpunte en persone maklik verlore gaan. Neem die geval Darwin. Ons lees dat Darwin nie sy evolusieteorie op fossielvondse gegrond het nie (p. 10), dat die ontruiming en vulling van ekologiese nisse sy siening van evolusie sou aantas en dat hy vir "meer as 20 jaar lank in die gerief en weelde van Down House, sy landhuis in Kent, gepieker het oor die vraag of hy sy teorie bekend moet maak" (p. 220). Vir Darwin was evolusie 'n vera causa, 'n omvattende en oorsaaklike verklaring wat in die werklike natuur waargeneem en van een stel verskynsels na 'n ander oorgedra kon word (Barnard 2004). Hy was 'n pynlik noukeurige navorser wat wyd en moeisaam empiriese stawing vir sy konsepte opgebou en nie voor 1854, twaalf jaar nadat hy in Down House ingetrek het, ernstig aan die manuskrip wat On the origin of species sou word, begin werk het nie. (Die boek het in 1859 verskyn.) Die skelette van uitgestorwe reuse-armadillo's en lui-diere ("sloths") wat Darwin in 1832 langs die kus van Patagonië gevind het, het hom van spesie-uitwissing oortuig; hy ervaar in 1835 'n aardbewing in die Chileense stad Concepcion en sien hoe skielik aardkorskragte 'n omgewing verander; die Galápagos-vinke wys hom hoe spesiasie omgewingsnisse kan vul (Barlow 1958). En soos die slotparagraaf van On the origin of species aantoon - Rousseau haal 'n gedeelte op p. 234 aan was hy net so meegevoer deur die wonder van lewe soos enige natuurteoloog van sy tyd (Darwin 1909:529).

'n Populêre wetenskap, in die vierde plek, gebruik feite, hipoteses en teorie nie net om in te lig nie maar dikwels om 'n saak te bepleit of te betwis. Selfs al stem 'n mens met hulle saam, bly Palmer se Perilous planet earth (2005) en Dawkins se The God delusion (2006) polemiekgeskrifte waarin opponente slegs oor 'n mindere deel van die waarheid sou beskik. Rousseau kom tot simpatie met Intelligente Ontwerp maar maak nie van sy teks 'n polemiek en bepleit nie IO as skoolvak nie. Trouens, hy stel dit dat sy lesers "Tussenspele", die derde afdeling van die boek waar wetenskaplike teorie en menslike bestaan ter sprake kom, "desgewens" kan uitlaat. Soms is Rousseau wel 'n bietjie goedvertrouend - soos oor Atlantis (pp. 317-320) - en 'n enkele keer weerspreek hy homself - soos oor die herkoms van die Witwatersrandse goud (pp. 52, 94).

Laastens steun Die groot avontuur op 'n versameling bronne waarvan $90 \%$ sekondêre literatuur of joernalistiek is, wat sin maak wanneer 'n skrywer lesers op 'n eie ontdekkingstog wil stuur. Die teks dra egter verwysings uit National Geographic, Nature, Natural History, Scientific American en Time wat nie in die bronnelys opgeneem is nie en die leser in onkunde oor hul konteks laat. Paul Johnson se "artikel" in The Spectator van 27 Augustus 2005 is byvoorbeeld uit een van sy weeklikse meningsrubrieke geneem waarin alles, van literêre kritiek tot studentepartytjies, ter sprake kom.

Rousseau se breë gevolgtrekking is dat gradualisme en saam daarmee Darwinisme in die wêreld van die wetenskap aan die terugval is. Hy staan ook heelwat ruimte af aan die uitwissings en spesiasies wat met katastrofes gepaard gaan en rapporteer in die laaste afdeling van die boek fassinerend oor 'n paar sulke episodes. Beteken dit nou dat neo-katastrofisme gradualisme vervang of bloot dat laasgenoemde fyner gekwalifiseer word? Hierdie resensent kies die tweede opsie. Lyell se beroemde aforisme, "The present is the key to the past", is in die eerste plek 'n navorsingstrategie en nie 'n suggestie dat die vorme van die aardkors onder alle omstandighede langsaam en gedrae sou ontwikkel nie. Soos Darwin in die opbou van die evolusieteorie, wou Lyell die geoloog lei om 
verklarings in die werklike wêreld op te spoor, om prosesse wat hy tans waarneem empiries te kan toets en oor te dra na ander verskynsels. Eers wanneer hulle faal, soek hy verklarings buite die hede maar dan is hy minder seker van sy afleidings. Vir die Kryt-Tersiêre impak beskik ons byvoorbeeld oor sterk bewyse maar die presiese meganismes van spesie-uitwissing bly kontroversieel en van die kleiner episodes sedertdien weet ons nog minder (McCarthy \& Rubridge 2005). Boonop hef katastrofes nie "normale geologiese" prosesse op nie, hoewel hulle tempo en aard vir kort tye mag verander. Stroomnetwerke behou hul strewe na orde, afsetting gaan voort, los sedimente kompakteer tot lae, magmas stol en tektoniese plate skuif. Per slot van sake is die iridium-ryke lagie wat Kryt- en Tersiêre gesteentes van mekaar skei slegs enkele sentimeter dik (Palmer 2005).

Die groot avontuur is die persoonlike soektog van iemand wat 'n doel in die eone-lange drama van lewe op aarde vermoed. Baie van ons mag Rousseau se teleologie afwys en sy vertolkings betwis, maar hy volg steeds die pad van die rede. Wetenskap se gevaarlikste vyande is die relativiste wat rede verwerp: postmoderniste vir wie rasionaliteit en wetenskap geen bevoorregting bo ander kenwyses het nie, wetenskapsosioloë wat die groei van kennis aan plaaslike konteks en gemeenskapsdinamiek toeskryf en taalfilosowe vir wie kennis bloot ' $n$ taalspel is. Die groot avontuur bly die moeite werd om te lees: vonkelend in aanbieding, vol menslike etos en omvattend in die debatte wat dit rapporteer. Soos 'n goeie populêre wetenskap daag die boek sy lesers uit om self verder te soek. Hulle sal egter nie van alles hou wat hulle vind nie.

\section{VERWYSINGS}

Barlow, N. 1958. The autobiography of Charles Darwin, 1809-1882. Londen (VK): Collins.

Barnard, W.S. 2004. Darwin at the Cape. Suid-Afrikaanse Tydskrif vir Wetenskap, 100: 243-248.

Darwin, C.R. 1909. The origin of species. Harvard Classics-reeks. New York (NY): Collier and Son.

Dawkins, R. 2006. The God delusion. New York (NY): Houghton Mifflin.

McCarthy, T., Rubidge, B. 2005. The story of life on earth: a Southern African perspective on a 4.6 billion years journey. Kaapstad: Struik.

Palmer, T. 2005. Perilous planet earth: catastrophes and catastrophism through the ages. Cambridge (VK): Cambridge University Press.

WILHELM S BARNARD

UNIVERSITEIT STELLENBOSCH

Maart 2007

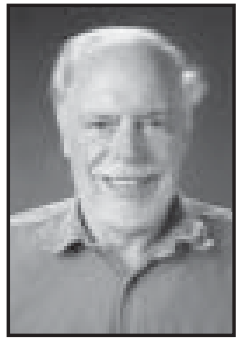

Barnie Barnard 